\title{
The version of microevolutionary relationships between the Siberian species Elymus margaritae, E. komarovii, and $E$. transbaicalensis (Poaceae) according to sequencing of the nuclear gene GBSS1 (waxy)
}

\author{
Alexander Agafonov ${ }^{1 *}$, Maria Emtseva $^{1}$, Elena Shabanova (Kobozeva) ${ }^{1}$, and Sergey \\ Asbaganov ${ }^{1}$ \\ ${ }^{1}$ Central Siberian Botanical Garden SB RAS, Zolotodolinskaya st., 101, Novosibirsk, Russia, 630090
}

\begin{abstract}
A comparative study was made of the sequence of the GBSS1 gene fragment in accessions of closely related species Elymus margaritae, E. komarovii, and E. transbaicalensis from Siberia. Nucleotide sequences of the gene were determined for St subgenomes in accessions of $E$. margaritae and E. komarovii from classical habitats. The StH-genomic constitution was confirmed, and microevolutionary relationships between species were evaluated by constructing the NJ dendrogram. It was shown that variants of the St subgenomes in accessions E. margaritae GUK-1009 and E. komarovii AUK-9803 belong to the North American ancestral line $\mathrm{St}_{2}$ of the genus Pseudoroegneria, in contrast to accessions E. margaritae AUK-0650 and E. komarovii GAR-0501. The latter belong to the Asian branch of $\mathrm{St}_{1}$, together with variants of subgenomes in the species $E$. gmelinii and E. pendulinus. That is, according to the differentiation levels of the St subgenome, accession E. margaritae GUK-1009 (holotype) is significantly distanted from the accession AUK-0650 (paratype), which in turn is close to accessions of E. komarovii and E. transbaicalensis from East Sayan. According to levels of differentiation of the H subgenome, the studied species did not show noticeable differences.
\end{abstract}

\section{Introduction}

The species Elymus margaritae A.V. Agaf., Kobozeva et B. Salomon was described in collectings from the Altai Republic (holotype: Ust-Koksinsky District, Krasnaya Gora; paratype: Kosh-Agachsky District, Ukok Plateau), but initially these accessions were referred to E. komarovii (Nevski) Tzvelev [1]. Before the description of the new species $E$. margaritae, plants were observed in conditions of open ground and climate chamber when generations changing.

\footnotetext{
* Corresponding author: agalex@mail.ru
} 
The conclusion was drawn, that specimens of the supposed new species maintained natural morphology, which is significantly different from the typical E. komarovii forms. Actual questions when studying a new E. margaritae species are its origination, variability, genetic specificity and crossability with other species.

Previously results were presented of the study of GBSS1 gene sequence in Elymus species from Siberian and Russian Far East areas to determine their genomic constitution and assess the phylogenetic differentiation [2]. Here the accession numbers of clones in GenBank NCBI are indicated. But no sequences from St genome were revealed in the sets of 8 sequenced clones of both E. komarovii GAR-0501 and E. margaritae GUK-1009 accessions. Therefore additional procedures of isolation and sequencing of GBSS1 genes from St genomes in these key accessions were performed, because GAR-0501 accession was gathered in the classical habitat of E. komarovii [3], and GUK-1009 accession - in the point of collecting of E. margaritae holotype [1,4].

The purpose of this research was to study the relationships of E. margaritae with morphologically close E. komarovii and E. transbaicalensis species, to reveal their specificity and possibility of mutual introgression.

\section{Materials and Methods}

Besides accessions of three mentioned species, the comparative research included clones of previously studied reference species from different regions of Asian Russia, which we assigned to two different groups according to $\mathrm{St}$ subgenome classification: E. kamczadalorum and E. jacutensis $\left(\mathrm{St}_{1}\right)$, E. kronokensis and E. caninus $\left(\mathrm{St}_{2}\right)$ (Table 1). Locations of accessions and authors of collectings were added in the publication [4]. Sequences of GBSS1 gene from species with $\mathrm{St}, \mathrm{H}$ and $\mathrm{Y}$ genomes were drawn from GenBank NCBI (http://www.ncbi.nlm.nih.gov/nuccore) (Table 2). Techniques of preparation of probes and GBSS1 sequences were carried out as described earlier [2]. The construction of dendrograms by Neighbor-Joining method was performed with TREECON ver. 1.3b software [5]. To avoid erroneous results of St clones sequencing in accessions $E$. komarovii GAR-0501 and E. margaritae GUK-1009, additional St clones of these accessions were used to construct the dendrogram.

Table 1. Clones of E. margaritae, E. komarovii, E. transbaicalensis accessions and 4 reference species of the genus Elymus, included in a comparative study of GBSSI gene sequences.

\begin{tabular}{|l|l|l|}
\hline Species & Accession & Clone (sequence in GenBank NCBI) \\
\hline $\begin{array}{l}\text { E. } \text { margaritae A.V. Agaf., Kobozeva } \\
\text { et Salomon }\end{array}$ & GUK-1009 & $\begin{array}{l}\text { marGUK09_4-St (MT263972) } \\
\text { marGUK09_1-H (MN164818) }\end{array}$ \\
\hline E. margaritae & AUK-0650 & $\begin{array}{l}\text { marAUK50_4-St (MN164819 } \\
\text { marAUK50_2-H (MN164820) }\end{array}$ \\
\hline E. komarovii (Nevski) Tzvel. & GAR-0501 & $\begin{array}{l}\text { komGAR01_3-St (MT263971) } \\
\text { komGAR01_2-H (MN136107) }\end{array}$ \\
\hline E. komarovii & AUK-9803 & $\begin{array}{l}\text { komAUK03_3-St (MN164816) } \\
\text { komAUK03_1-H (MN164817) }\end{array}$ \\
\hline E. transbaicalensis (Nevski) Tzvel. & GAR-0530 & $\begin{array}{l}\text { trnGAR30_4-St (MN164821) } \\
\text { trnGAR30_1-H (MN164822) }\end{array}$ \\
\hline E. kamczadalorum (Nevski) Tzvel. & KSO-9623 & $\begin{array}{l}\text { kamKSO23_1-St (MN126577) } \\
\text { kamKSO23_2-H (MN126576) }\end{array}$ \\
\hline E. jacutensis (Drob.) Tzvel. & 12-0135 & $\begin{array}{l}\text { jac0443_1-St (MN136106) } \\
\text { jac0443_5-H (MN136105) }\end{array}$ \\
\hline E. kronokensis (Kom.) Tzvel. & KES-9603 & $\begin{array}{l}\text { kroKES03_2-St (MN126581) } \\
\text { kroKES03_1-H (MN126580) }\end{array}$ \\
\hline E. caninus (L.) L. & ABZ-1654 & canABZ54_2-St (MN164839) \\
\hline
\end{tabular}




\begin{tabular}{|l|l|l|}
\hline & & canABZ54_1-H (MN164840) \\
\hline
\end{tabular}

Table 2. Species accessions and their clones drawn from the GenBank NCBI.

\begin{tabular}{|l|l|l|l|}
\hline Species & Accession (origin) & $\begin{array}{l}\text { Sequence in } \\
\text { GenBank NCBI } \\
\text { (source*) }\end{array}$ & $\begin{array}{l}\text { Designation on } \\
\text { dendrograms }\end{array}$ \\
\hline $\begin{array}{l}\text { Elymus gmelinii (Ledeb.) } \\
\text { Tzvel. }\end{array}$ & PI 499447 China & $\begin{array}{l}\text { St GQ847726 } \\
\text { Y GQ847727 }\end{array}$ & $\begin{array}{l}\text { gme_7726_S } \\
\text { gme_7727_Y }\end{array}$ \\
\hline $\begin{array}{l}\text { E. pendulinus } \text { (Nevski) } \\
\text { Tzvel. }\end{array}$ & PI 499452 China & $\begin{array}{l}\text { St GQ847731 } \\
\text { Y GQ847732 }\end{array}$ & $\begin{array}{l}\text { pen_7731_S } \\
\text { pen_7732_Y }\end{array}$ \\
\hline $\begin{array}{l}\text { Pseudoroegneria strigosa } \\
\text { (M.Bieb.) A. Löve }\end{array}$ & PI 499637 China & St EU282323 & Ps.str_323 \\
\hline P. strigosa & PI 531755 China & St AY360823 & Ps.str_823 \\
\hline P. spicata (Pursh) A. Löve & PI 232117 USA & St AF079281 & P.spi_281 \\
\hline P. spicata & PI 610986 USA & St AY010999 & P.spi_999 \\
\hline Hordeum jubatum L. & RJMG 106 USA & H AY010963 & H.jub_63_H \\
\hline $\begin{array}{l}\text { H. brevisubulatum (Trin.) } \\
\text { Link }\end{array}$ & PI 401387 Iran & H AY0109615 & H.bre_61_H \\
\hline Bromus tectorum L. & & AY362757 & Bromus_AY3 \\
\hline
\end{tabular}

${ }^{1}[6] ;{ }^{2}[7] ;{ }^{3}[8] ;{ }^{4}[9] ;{ }^{5}[10]$.

\section{Results and Discussions}

The dendrogram built on the basis of nucleotide sequences of GBSS1 gene in St and $\mathrm{H}$ subgenomes is shown in Fig. 1. It confirms the StH-genomic constitution of studied species. It is shown, that variants of St subgenomes of E. margaritae GUK-1009 and E. komarovii AUK-9803 accessions belong to the North American ancestral line $\mathrm{St}_{2}$ of Pseudoroegneria genus together with reference species E. caninus and E. kronokensis, unlike the accessions of E. margaritae AUK-0650 and E. komarovii GAR-0501. The latter accessions most probably belong to Asian $\mathrm{St}_{1}$ clade with St subgenome variants of $E$. gmelinii and E. pendulinus species [2]. Studied species showed no noticeable differences on levels of $\mathrm{H}$ subgenome differentiation, but they confirmed their belonging to the evolutional $\mathrm{H}_{1}$ variant in contrast to the reference E. kamczadalorum and E. jacutensis species, related to $\mathrm{H}_{2}$ variant.

The main differences between subgenome variants $\mathrm{St}_{1}$ and $\mathrm{St}_{2}$ were in 11,12 and 13 introns of GBSS1 gene and are as follows. Clones with $\mathrm{St}_{2}$ variant have insertions of $8 \mathrm{bp}$ (GCCTCCTC), 3 bp (CAG), 2 bp (TT), 1 bp (C and A), which are lack in $\mathrm{St}_{1}$, and they doesn't have insertions of $3 \mathrm{bp}(\mathrm{GTA})$ and $1 \mathrm{bp}(\mathrm{T})$, which present in $\mathrm{St}_{1}$-subgenomic clones. The two variants of St subgenome also differ from each other by substitutions: GT in $\mathrm{St}_{2}$ was substituted by $\mathrm{AG}$ in $\mathrm{St}_{1}$, TAT was substituted by CCG, CT - by TC, GT - by $\mathrm{CA}$, and $\mathrm{AT}-$ by CC. In addition, clones with $\mathrm{St}_{1}$ and $\mathrm{St}_{2}$ variants differ by substitutions of single nucleotides: 17 transitions $(3 \mathrm{~A} / \mathrm{G}$ and $14 \mathrm{C} / \mathrm{T})$ and 10 transversions $(1 \mathrm{~A} / \mathrm{T}, 5 \mathrm{~A} / \mathrm{C}, 2$ $\mathrm{C} / \mathrm{G}$ and $2 \mathrm{G} / \mathrm{T}$ ). These distinctions allowed clones with $\mathrm{St}_{1}$ and $\mathrm{St}_{2}$ subgenome variants to be separated into different clades. 


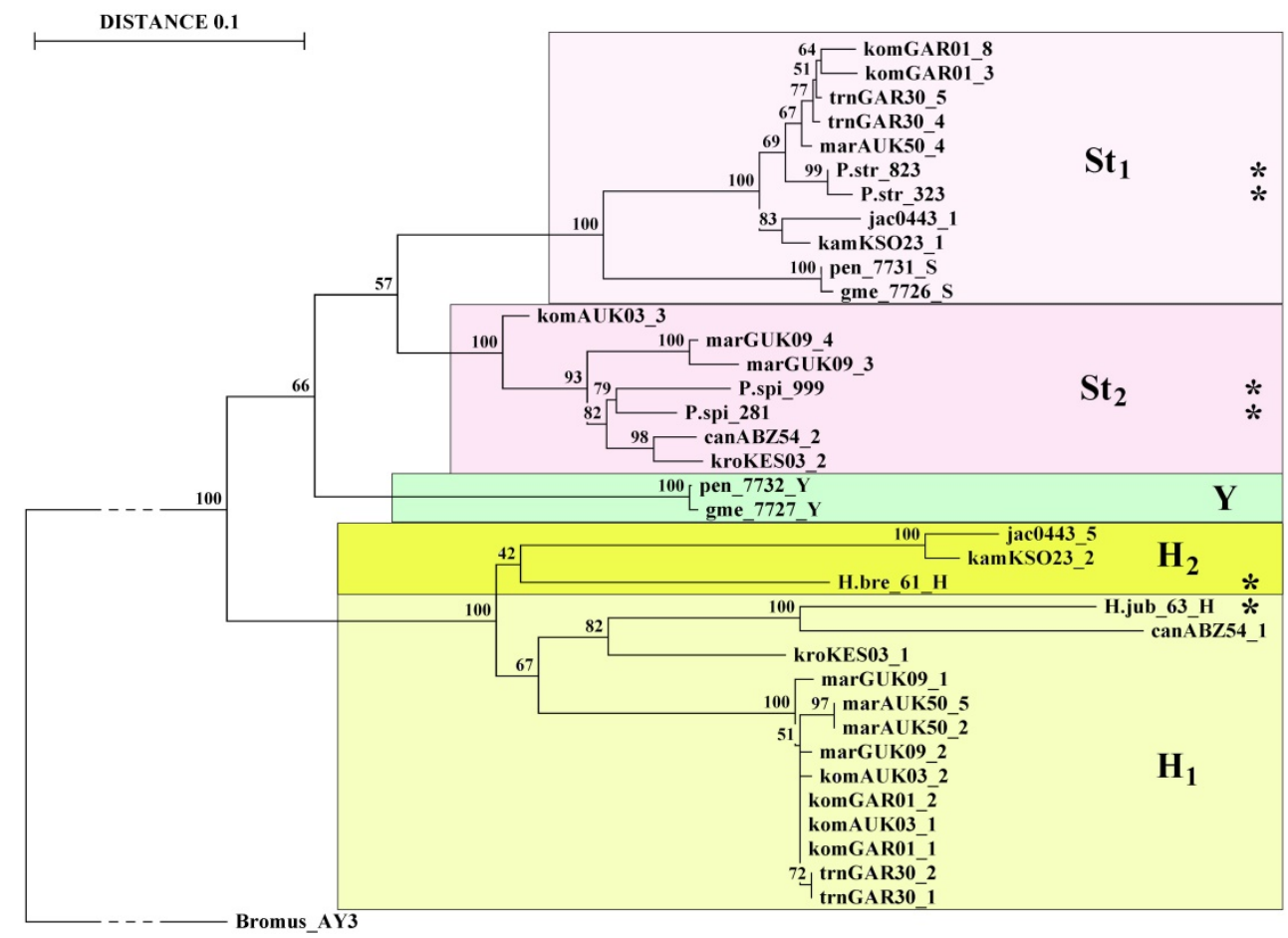

Fig.1. The NJ dendrogram based on the analysis of GBSS1 gene sequences (exons and introns from 9 through 14) of the Siberian species E. komarovii, E. transbaicalensis and E. margaritae in comparison with the reference species from the NCBI GenBank. Asterisks indicate species monogenomic carriers of the St and $\mathrm{H}$ subgenomes.

The main differences between $\mathrm{H}$ and St subgenomes of GBSS1 gene are in the presence of sequences in St-subgenomic clones, which are absent in H-subgenomic carriers: $17 \mathrm{bp}$ (with single distinctions in it between $\mathrm{St}_{1}$ and $\mathrm{St}_{2}$ subgenomes), $2 \mathrm{bp}$ (TT), 3 bp (AGT) and $4 \mathrm{bp}$ (CATT). H-subgenomic clones also differ from St-subgenomic ones by a number of substitutions of 2, 3, 4, $5 \mathrm{bp}$, and by 52 single nucleotide substitutions: 32 transitions (16 $\mathrm{C} / \mathrm{T}$ and $16 \mathrm{~A} / \mathrm{G})$ and 20 tansversions $(8 \mathrm{~A} / \mathrm{C}, 4 \mathrm{G} / \mathrm{T}, 5 \mathrm{G} / \mathrm{C}$ and $3 \mathrm{~A} / \mathrm{T})$.

$\mathrm{H}$-subgenomic clones have several short sequences, identical with $\mathrm{St}_{2}$-subgenomic clones, but differing from $\mathrm{St}_{1}$-subgenomic ones. So, $\mathrm{H}$ and $\mathrm{St}_{2}$ subgenomes have sequences $6 \mathrm{bp}$ (GCCTCC), 2 bp (TT) and $1 \mathrm{bp}$ (C and A), which are absent in $\mathrm{St}_{1}$. Also $\mathrm{H}$ and $\mathrm{St}_{2}$ subgenomes have substitutions compared to $\mathrm{St}_{1}$ subgenome: $\mathrm{GT}$ in $\mathrm{H}$ and $\mathrm{St}_{2}$ substituted by $\mathrm{AG}$ in $\mathrm{St}_{1}$, TAT - by CCG, CT - by TC, and GT - by CA.

Clones of E. kamczadalorum, E. jacutensis, E. kronokensis and E. caninus with Hsubgenome have an insertion of $2 \mathrm{bp}$ in 9 intron, which is absent in all other clones, but presents in Hordeum jubatum clone. H-subgenomic clone of E. caninus have substitutions of 2, 3, 4, $6 \mathrm{bp}$ and two deletions of 4 and $5 \mathrm{bp}$ in 10 intron, which are identical to those of $H$. jubatum clone and absent in all other clones. This probably influenced the isolation of clone canABZ54_1 with $H$. jubatum clone into the separate clade within the common clade with H-subgenomic accessions. Clone canABZ54_1 have substitutions of 3, 3 and 4 bp in 12 intron compared to all other clones, among which first two substitutions are identical to those of E. kronokensis clone, what also has been reflected on dendrogram.

Clones of E. gmelinii and E. pendulinus - gme7727_Y and pen7732_Y - have a substitution of $3 \mathrm{bp}$ (GAT) in 12 intron and insertion of $2 \mathrm{bp}$ (CA) in 13 intron, due to what they separated into $\mathrm{Y}$-subgenomic clade. 
Thus, according to differentiation levels of the St subgenome, the accession E. margaritae GUK-1009 (holotype) is significantly separated from the AUK-0650 accession (paratype), which, in turn, is close to E. komarovii and E. transbaicalensis accessions from East Sayan.

At the same time our previous research has shown that accession AUK-0650 of $E$. margaritae contains clones of GBSS1 gene both with $\mathrm{St}_{1}$ and $\mathrm{St}_{2}$ subgenome variants [2]. This phenomenon demonstrates the appearance of controversial results when comparing data of morphology and molecular genetics. Nevertheless, close clustering of clones of studied species on the dendrogram is consistent with obtained preliminary data about the tendency of species to mutual introgression.

This work was supported by the state project "Estimation of the morphogenetic potential of the North Asian plant population by experimental methods" (state registration number: AAAA-A17117012610051-5) for the Central Siberian Botanical Garden (CSBG) SB RAS, with partial financial support of the Russian Foundation for Basic Research (project No. 18-04-01030). Materials of the bioresource scientific collection of the CSBG SB RAS "Collections of living plants in open and closed ground", USU No. 440534 were used.

\section{References}

1. A.V. Agafonov, E.V. Kobozeva, B. Salomon, Plant life of Asian Russia, 4, 36-40 (2015) (In Russian)

2. A.V. Agafonov, S.V. Asbaganov, E.V. Shabanova (Kobozeva), I.V. Morozov, A.A. Bondar, Vavilov Journal of Genetics and Breeding, 23, 817-826 (2019)

3. S.A. Nevksy, Bulletin of Botanical Garden of AS of the USSR, 30, 607-635 (1932) (In Russian)

4. A.V. Agafonov, E.V. Shabanova (Kobozeva), S.V. Asbaganov, A.V. Mglinets, V.S. Bogdanova, Vavilov Journal of Genetics and Breeding, 24, 115-122 (2020)

5. Y. Van de Peer, R. De Wachter, Comp. Appl. Biosci., 10, 569-570 (1994)

6. R.J. Mason-Gamer, M.M. Burns, M. Naum, Mol. Phyl. Evol., 54, 10-22 (2010)

7. R.J. Mason-Gamer, Mol. Phyl. Evol. 47, 598-611 (2008)

8. R.J. Mason-Gamer, Syst. Biol. 53, 25-37 (2004)

9. R.J. Mason-Gamer, C.F. Weil, E.A. Kellogg, Mol. Biol. Evol., 15, 1658-1673 (1998)

10. R.J. Mason-Gamer, Systematic Botany, 26, 757-768 (2001) 